\title{
PENGGUNAAN MODEL EVALUASI RESPONSIVE STAKE PADA PROGRAM PEMBELAJARAN PPKn KELAS VII MTS LABUAN BAJO KABUPATEN MANGGARAI BARAT
}

\author{
Abidin', Hafsah² \\ ${ }^{1}$ Pendidikan Pancasila dan Kewarganegaraan, Universitas Muhammadiyah Mataram, abidin24@gmail.com \\ ${ }^{2}$ Pendidikan Pancasila dan Kewarganegaraan, Universitas Muhammadiyah Mataram, dansa.manchi@yahoo.co.id
}

INFO ARTIKEL
Riwayat Artikel:
Diterima: $\quad 27-F e b r a u r i-$
2018
Disetujui: $29-M a r e t-2018$

Kata Kunci:

Evaluasi

Responsive stake

Pembelajaran PPKn

\begin{abstract}
Abstrak: Penelitian ini bertujuan untuk membandingkan kesesuaian antara program pembelajaran PPKn yang meliputi tahap perencanaan, proses dan hasil belajar dengan permendikbud No. 22 tahun 2016 mengenai standar proses pendidikan dasar dan menengah menggunakan model evaluasi responsive stake. Pendekatan penelitian yang digunakan yaitu pendekatan deskriptif kualitatif. Pengumpulan data yang digunakan adalah observasi, dokumentasi dan wawancara. Dari temuan dan hasil penelitian menunjukkan bahwa program pembelajaran PPKn di MTS Labuan Bajo Kabupaten Manggarai Barat, pada tahap perencanaan telah sesuai dengan permendikbud no. 22 tahun 2016 tentang standar proses pendidikan dasar dan menengah, pada tahap pelaksanaan pembelajaran belum sesuai dengan permendikbud No. 22 tahun 2016 tentang standar proses pendidikan dasar dan menengah, dan hasil belajar telah sesuai dengan permendikbud No. 22 tahun 2016 tentang standar proses pendidikan dasar dan menengah. Jadi dapat program pembelajaran PPKn di MTS Labuan Bajo Kabupaten Manggarai Barat secara keseluruhan belum sesuai dengan permendikbud no. 22 tahun 2016 tentang standar proses pendidikan dasar dan menengah.
\end{abstract}

\begin{abstract}
This study aims to compare the suitability between the PPKn learning program which includes the planning, process and learning outcomes with Permendikbud No. 22 of 2016 concerning the standard process of primary and secondary education using a responsive stake evaluation model. The research approach used is a qualitative descriptive approach. Data collection used is observation, documentation and interviews. The findings and results of the study indicate that the PPKn learning program in MTS Labuan Bajo, West Manggarai Regency, at the planning stage was in accordance with the Minister of Education and Culture no. 22 of 2016 concerning the standard process of primary and secondary education, at the stage of implementation of learning not in accordance with Minister of Education and Culture No. 22 of 2016 concerning the standard process of primary and secondary education, and learning outcomes in accordance with Minister of Education and Culture No. 22 of 2016 concerning standards for the process of primary and secondary education. So can the PPKn learning program in MTS Labuan Bajo, West Manggarai Regency as a whole not be in accordance with the Minister of Education and Culture no. 22 of 2016 concerning standards for the process of primary and secondary education.
\end{abstract}

\section{A. LATAR BELAKANG}

Mata pelajaran PPKn merupakan mata pelajaran hasil penyempurnaan dari mata pelajaran pendidikan kewarganegaraan (PKn) yang semula dikenal dalam Kurikulum 2006. Sehingga dalam hal ini, arah pengembangan mata pelajaran PPKn, dijiwai oleh 4 (empat) konsensus kebangsaan yang meliputi: Pancasila, Undang-Undang Dasar Negara Republik Indonesia Tahun 1945, Negara Kesatuan Republik Indonesia, dan Bhinneka Tunggal Ika. Sementara itu, landasan operasionalnya terdapat dalam Undang-Undang No. 20 tahun 2003 tentang Sistem Pendidikan Nasional Bab II tentang dasar, fungsi dan tujuan pasal (2) yang berbunyi
"Pendidikan nasional berdasarkan Pancasila dan Undang-Undang Dasar Negara Republik Indonesia Tahun 1945". Selanjutnya pasal (3) menjelaskan bahwa:

Pendidikan nasional berfungsi mengembangkan kemampuan dan membentuk watak serta peradaban bangsa yang bermartabat dalam rangka mencerdaskan kehidupan bangsa, bertujuan untuk berkembangnya potensi peserta didik agar menjadi manusia yang beriman dan bertakwa kepada Tuhan Yang Maha Esa, berakhlak mulia, sehat, berilmu, cakap, kreatif, mandiri, dan menjadi warga negara yang demokratis serta bertanggungjawab.

Penerapan proses pembelajaran seorang guru dapat mengukur kemampuan peserta didik yaitu: (1) Afektif, 
Sesuai dengan karakteristik sikap, maka salah satu alternatif yang di pilih adalah proses afeksi mulai dari menerima, menjalankan, menghargai, menghayati, hingga mengamalkan.; (2) Kognitif, Pengetahuan dimiliki melalui aktivitas mengetahui, memahami, menerapkan, menganalisis, dan mengevaluasi. Karakteritik aktivititas belajar dalam domain pengetahuan ini memiliki perbedaan dan kesamaan dengan aktivitas belajar dalam domain keterampilan.; dan (3) Psikomotorik, Keterampilan diperoleh melalui kegiatan mengamati, menanya, mencoba, menalar, menyaji, dan mencipta.

Namun demikian, sebagaimana hasil pengumpulan perangkat pembelajaran yang dilaksanakan di MTS Labuan Bajo Kab. Manggarai Barat, kenyataan yang muncul saat ini terkait dengan program pembelajaran PPKn pada tiga tahapan yaitu:

Pertama pada aspek perencanaan pembelajaran, masih adanya guru-guru yang belum sepenuhnya melaksanakan konsep pembelajaran PPKn secara sistematis yang sesuai dengan Permendikbud No. 22 Tahun 2016 tentang Standar Proses Pendidikan Dasar dan Menengah, adanya fenomena guru yang melakukan plagiat terhadap RPP yang dibuat oleh pemerintahdan guru kurang dalam melaksanakan pelatihan implementasi kurikulum 2013.

Kedua pada aspek pelaksanaan pembelajaran, guru sering kali tidak secara tuntas mengimplementasikan RPP dalam kegiatan proses belajar mengajar, tidak adanya pemberian motivasi belajar kepada peserta didik secara kontekstual sesuai kehidupan sehari-hari, guru tidak mengajukan pertanyaan-pertanyaan yang mengaitkan pengetahuan sebelumnya dengan materi yang akan dipelajari, guru tidak menjelaskan uraian kegiatan yang akan dilakukan sesuai silabus.

Ketiga pada aspek penilaian hasil pembelajaran, banyak guru yang mengesampingkan penilaian terhadap sikap religius dan sosial, guru masih belum memahami kesesuaian penilaian dengan tujuan pembelajaran, guru tidak melengkapi instrumen penilaian yang mencakup soal, kunci jawaban, dan rubrik, guru tidak melakukan program remedial terhadap hasil belajar peserta didik yang masih di bawah KKM, dan guru tidak memberikan pengayaan terhadap hasil belajar peserta didik yang sudah mencapai standar KKM.

Berdasarkan permasalahan yang terjadi di lapangan peneliti mencoba menggunkan Model evaluasi responsive Stake untuk mengevalusi program pembelajaran PPKn kelas VII di MTS Labuan bajo. Model evaluasi responsive terdiri atas dua matriks. Matriks pertama dinamakan matriks deskripsi dan yang kedua dinamakan matriks pertimbangan. Evaluasi model memberikan deskripsi dan pertimbangan sepenuhnya mengenai pembelajaran PPKn yang dilakukan oleh guru PPKn. Dalam model ini Stake sangat menekan kan peran evaluator dalam mengembangkan tujuan pembelajaran PPKn menjadi tujuan khusus dan terukur.

Dari pemaparan permasalahan dan penelusuran hasil penelitian sebelumnya, peneliti tertarik untuk melakukan penelitian evaluasi pembelajaran yang meliputi tahapan: perencanaan, pelaksanaan, dan penilaian hasil pembelajaran dengan menggunakan model responsive pada mata pelajaran PPKn. Hal ini didasarkan pada Peraturan Menteri Pendidikan dan Kebudayaan Republik Indonesia No. 22 Tahun 2016 tentang Standar Proses Pendidikan Dasar dan Menengah. Pusat analisisnya adalah bagaimana melihat kesesuaian perencanaan, pelaksanaan, dan penilaian hasil pembelajaran yang sedang dilakukan oleh guru sesuai dengan Standar tersebut, sehingga nantinya akan diberikan suatu pertimbangan dan rekomendasi terhadap apa yang sedang dilakukan oleh guru selama ini terkait dengan ketiga tahapan program pembelajaran tersebut.

Tujuan penelitian ini untuk mengetahui yaitu 1) Penggunaan model evaluasi responsive Stake dapat mengetahui perkembangan prestasi belajar siswa pembelajaran; 2) Penggunaan model evaluasi Responsive Stake dapat mengetahui proses pembelajaran PPKn; 3) Pelaksanaan pembelajaran PPKn yang dilakukan dalam bentuk kegiatan pembelajaran sesuai tidak dengan perencanaan yang dibuat dalam bentuk RPP menggunakan model evaluasi Responsive Stake.

\section{B. METODE PENELITIAN}

1. Jenis Penelitian

Jenis penelitian ini merupakan penelitian evaluasi (evaluation research). Penelitian evaluasi merupakan suatu desain dan prosedur evaluasi dalam mengumpulkan dan menganalisis data secara sistematis untuk menentukan nilai atau manfaat (worth) dari suatu praktik pendidikan berdasarkan atas hasil pengukuran atau pengumpulan data dengan menggunakan standar atau kriteria tertentu yang digunakan secara absolut maupun relatif[1].

Model evaluasi yang digunakan yaitu model evaluasi responsive Stake yang menyatakan bahwa penekanan evaluasi pada dua jenis operasional, yaitu deskripsi dan pertimbangan serta membedakan dua tahapan dalam evaluasi yaitu perencanaan dan proses. Model ini dipilih karena peneliti ingin mengetahui pembelajaran yang sedang dilaksanakan oleh guru dari sudut perencanaan, pelaksanaan, dan hasil pembelajaran sehingga sesuai dengan model evaluasi responsive Stake.

Pendekatan penelitian ini menggunakan pendekatan deskriptif kualitatif. Bogdan \& Taylor mengatakan bahwa "penelitian kualitatif sebagai penelitian yang menghasilkan data deskriptif berupa kata-kata tertulis atau lisan"[2]. Dengan perkataan lain, penelitian kualitatif merupakan penelitian yang menghasilkan data deskriptif dan berupaya menggali dari suatu fonomena. 
Desain penelitian ini menggunakan model evaluasi responsive yang dikembangkan Stake seperti pada di bawah ini. Sebagaimana desain penelitian model evaluasi Responnsive Stake yang dijelaskan, maka akan dijelaskan secara rinci prosedur atau tahapan yang dilakukan oleh peneliti sebagai berikut:

a. pada bagian rasional pembelajaran PPKn yaitu menjelaskan pentingnya suatu evaluasi pembelajaran PPKn yang dalam perihal ini berkaitan dengan evaluasi pada tahapan perencanaan, pelaksanaan, dan penilaian hasil pembelajaran PPKn;

b. pada tahap Intens ini dilakukan pengumpulan data yang berkaitan dengan informasi tentang tujuan dari pembelajaran PPKn yang diharapkan. Analisis tujuan ini dilakukan pada tiga komponen evaluasi yaitu: Antecedents (perencanaan pembelajaran PPKn), Transactions (pelaksanaan pembelajaran PPKn), dan Outputs (penilaian hasil pembelajaran PPKn);

c. pada tahap Observation ini bagaimana melihat apa yang sesungguhnya terjadi di lapangan terkait dengan ketiga komponen evaluasi tersebut;

d. antara Intens dan Observation tersebut terdapat Contingency Logis dan Contingency Empiric. Contingency Logis adalah hasil pertimbangan evaluator terhadap keterkaitan atau keselarasan logis antara kotak Antecedents (perencanaan pembelajaran PPKn) dengan Transactions (pelaksanaan pembelajaran PPKn) dan Outputs (penilaian hasil pembelajaran PPKn). Evaluator juga memberikan pertimbangan keterkaitan empirik, berdasarkan data lapangan, antara Antecedents, Transactions, dan Outputs mengenai Congruence atau kesesuaian yang terjadi antara apa yang dikerjakan dengan apa yang terjadi di lapangan;

e. analisis Congruence terlebih dahulu dengan cara menyusun standar pengukuran keterlaksanaan pembelajaran pada semua tahap evaluasi dengan menyusun kriteria-kriteria yang jelas dan terukur. Standar yang digunakan oleh evaluator dalam penelitian ini adalah Peraturan Menteri Pendidikan dan Kebudayaan Nomor 22 Tahun 2016 Tentang Standar Proses Pendidikan Dasar dan Menengah;

f. analisis terhadap kesesuaian standar dengan data hasil penelitian akan menjadi dasar dalam pengambilan keputusan (Judgement). Pengambilan keputusan ini dilaksanakan untuk ketiga komponen evaluasi yaitu Antecedents (perencanaan pembelajaran PPKn), Trasactions (pelaksanaan pembelajaran PPKn), dan Outputs (penilaian hasil pembelajaran PPKn); dan

g. langkah terakhir yang dilakukan adalah memberikan rekomendasi terhadap hasil pertimbangan yang dilakukan sebelumnya berdasarkan hasil evaluasi.

2. Subjek Penelitian
Subjek penelitian merupakan sesuatu yang kedudukannya sangat sentral karena pada subjek penelitian itulah data tentang variabel yang diteliti berada dan diamati oleh peneliti[3]. Berdasarkan pendapat tersebut, maka yang menjadi subjek penelitian dalam penelitian ini adalah guru khususnya pada mata pelajaran PPKn yang mengajar di MTs Labuan Bajo Kab. Manggarai Baratyang telah menerapkan Kurikulum 2013.

Pengambilan subjek penelitian dilakukan dengan teknik Purposive Sampling. Purposive Sampling adalah teknik penentuan sampel dengan pertimbangan tertentu (Sugiyono, 2015: 124). Jumlah subjek penelitian berdasarkan kriteria pengambilan sampel pada guru khususnya mata pelajaran PPKn yang mengajar di MTs Labuan Bajo Kab. Manggarai Barat yang telah menerapkan Kurikulum 2013 lebih tepatnya di kelas yaitu kelas VII. Adapun kriteria enam guru PPKn yang mengajar di sekolah tersebut yaitu: (1) Guru PPKn yang sudah tersertifikasi, (2) Guru PPKn yang sudah mengikuti beberapa kali pelatihan implementasi Kurikulum 2013, (3) Guru PPKn yang berasal dari lulusan Sarjana PPKn, dan (4) Masa kerja yang cukup lama.

3. Lokasi Penelitian

Lokasi/tempat dilakukannya penelitian ini adalah di MTS Labuan Bajo. Peneliti memilih sekolah MTs Labuan Bajo Kab. Manggarai Barat karena sekolah tersebut merupakan salah satu sekolah di kabupaten Manggarai Barat yang telah menerapkan Kurikulum 2013. Sekolah ini terletak di kompleks MTS Labuan Bajo Jalan Puncak Waringin.

4. Pengumpulan Data

a. Wawancara

Wawancara (interview) merupakan salah satu bentuk teknik pengumpulan data yang banyak digunakan dalam penelitian deskriptif kualitatif dan deskriptif kuantitatif. Sebagaimana yang dikemukakan oleh Sukmadinata[1], bahwa teknik wawancara yang digunakan dalam penelitian ini yaitu wawancara terstruktur atau siatematis yaitu wawancara yang dimana peneliti menggunakan pedoman wawancara yang telah tersusun secara sistematis dan lengkap untuk pengumpulan datanya, pedoman wawancara yang digunakan hanya berupa garis-garis besar permasalahan yang akan ditanyakan[4].

b. Observasi

Observasi adalah "suatu metode pengumpulan data dengan mengamati secara langsung maupun secara tidak langsung terhadap kegiatan-kegiatan yang sedang berlangsung. Dengan kata lain observasi adalah pengamatan yang dilakukan dengan menggunakan alat indera, baik langsung maupun tidak langsung terhadap fakta-fakta atau gejala-gejala yang diteliti. Teknik obsevasi yang digunakan untuk membuktikan kebenaran dan informasi yang diperoleh dari wawancara[5].

c. Dokumentasi 
Dokumentasi merupakan catatan peristiwa yang sudah berlalu. Dokumentasi bisa berbentuk tulisan, gambar, atau karya-karya monumental dari seseorang. Dokumen yang berbentuk tulisan misalnya catatan harian, sejarah kehidupan (life histories), ceritera, biografi, peraturan, dan kebijakan. Dokumentasi yang berbentuk gambar misalnya foto, gambar hidup, sketsa, dan lain-lain.dokumentasi yang berbentuk karya misalnya karya seni, yang dapat berupa gambar, patung, film, dan lain-lain[4].

\section{Analisis Data}

Menurut Sugiyono, (2012 :142) Analisis data dalam penelitian kualitatif, dilakukan pada saat pengumpulan data berlangsung, dan setelah pengumpulan data dalam periode tertentu. Pada saat wawancara, peneliti sudah melakukan análisis terhadap jawaban yang diwawancarai. Aktifitas dalam análisis data, yaitu reductio, data display, dan conclusión drawing/verification.

\section{a. Data reduction (reduksi data)}

Data yang diperoleh dari lapangan jumlahnya cukup banyak, untuk itu maka perlu dicatat secara teliti dan rinci, seperti telah dikemukakan, semakin lama peneliti di lapangan, maka jumlah semakin banyak, kompleks dan rumit. Dengan demikian data yang direduksi akan memberikan gambaran yang lebih jelas, dan mempermudah peneliti untuk melakukan pengumpulan data selanjutnya, dan mencari bila diperlukan. Reduksi data dapat di bantú dengan peralatan elektronik seperti komputer mini, dengan memberikan kode pada aspekaspek tertentu.

b. Data display (penyajian data)

Setelah data direduksi, maka langkah selanjutnya adalah mendisplaykan data kalau dalam penelitian kualitatif penyajian data ini dapat dilakukan dalam bentuk tabel, grafik, phie chard, pictogram dan sejenisnya. Melalui penyajian data tersebut, maka data terorganisasikan, tersusun dalam pola hubungan, sehingga akan mudah dipahami. Dalam penelitian kualitatif, penyajian data bisa dilakuakan dalam bentuk uraian singkat, bagan, hubungan antara kategori, flowchard dan dan sejenisnya.

c. Conclusión drawing/(Kesimpulan)

Langkah ke tiga dalam penelitian kualitatif menurut Miles dan Huberman adalah penarikan kesimpulan verifikasi. Kesimpulan awal yang dikemukakan masih bersifat sementara, dan akan berubah bila tidak ditemukan bukti-bukti yang kuat yang mendukung pada tahap pengumpulan data yang berikutnya. Dengan demikian kesimpulan dalam penelitian kualitatif mungkin dapat jawab rumusan masalah yang yang dirumuskan sejak awal, tetapi mungkin juga tidak, karena seperti telah ditemukakan bahwa masalah dan rumusan masalah dalam penelitian kualitatif masih bersifat sementara dan akan berkembang setelah penelitian berada di lapangan.

\section{HASIL DAN PEMBAHASAN}

1. Perencanaan Pembelajaran

Sebelum melakukan proses pengamatan pelaksanaan pembelajaran peneliti terlebih dahulu melakukan wawancara dan dokumentasi terkait dengan perencanaan pembelajaran PPKn yang telah disusun oleh guru dalam bentuk RPP (Rencana Pelaksanaan Pembelajaran).

Peneliti mempersiapkan dokumen RPP (Rencana Pelaksanaan Pembelajaran) dan pedoman wawancara yang telah diuraikan dalam bentuk pertanyaan, yaitu sebagai berikut:

Apakah menuliskan nama satuan pendidikan? (Ya), apakah menuliskan mata pelajaran? (Ya), apakah menuliskan kelas dan semester? (Ya), apakah menuliskan materi pokok? (Ya), apakah menuliskan jumlah pertemuan dan jumlah jam pelajaran (alokasi waktu) ? (Ya), apakah menuliskan Kompetensi Inti-1? (Ya), apakah menuliskan Kompetensi Inti-2? (Ya), apakah menuliskan Kompetensi Inti-3? (Ya), apakah menuliskan Kompetensi Inti-4? (Ya), apakah menuliskan Kompetensi Dasar pada KI-1? (Ya), apakah menuliskan Kompetensi Dasar pada KI-2? (Ya), apakah menuliskan Kompetensi Dasar pada KI-3? (Ya), apakah menuliskan Kompetensi Dasar pada KI-4? (Ya), apakah merumuskan indikator sesuai dengan Kompetensi Dasar? (Ya), apakah menggunakan kata kerja operasional relevan dengan Kompetensi Dasar yang dikembangkan? (Ya), apakah merumuskanindikator yang mencakup kompetensi pengetahuan, keterampilan, dan sikap? (Ya), apakah merumuskan indikator dengan jumlah cukup sebagai penanda ketercapaian Kompetensi Dasar? (Ya), apakah merumuskan tujuan pembelajaran sesuai indicator? (Ya), apakah merumuskn tujuan pembelajaran yang mencakup kompetensi pengetahuan, sikap, dan keterampilan? (Ya), apakah merumuskan tujuan pembelajaran sesuai dengan alokasi waktu, kompleksitas KD, dan sarana dan prasarana yang tersedia? (Tidak), apakah memilih materi pembelajaran regular sesuai dengan kompetensi yang akan dikembangkan? (Ya), apakah memilih materi pembelajaran pengayaan sesuai dengan kompetensi yang akan dikembangkan? (Ya), apakah kedalaman materi pembelajaran regular sesuai kemampuan peserta didik? (Ya), apakah kedalaman materi pembelajaran pengayaan sesuai kemampuan peserta didik? (Ya), apakah cakupan materi pembelajaran regular sesuai dengan alokasi waktu dan sarana pendukung? (Ya), apakah cakupan materi pembelajaran pengayaan sesuai dengan alokasi waktu dan sarana pendukung? (Ya), apakah menentukan metode pembelajaran yang sesuai dengan Kompetensi Dasar? (Ya), apakah menentukan metode pembelajaran yang sesuai dengan karakteristik peserta didik? (Ya), apakah memanfaatkan media pembelajaran sesuai dengan tujuan pembelajaran? (Tidak), apakah memanfaatkan variasi media pembelajaran sesuai dengan arahan pada buku pegangan guru dan siswa? (Ya), apakah memanfaatkan media pembelajaran untuk mewujudkan pembelajaran dengan pendekatan saintifik secara optimal? (Tidak), 
apakah memilih media, alat, dan bahan sesuai dengan karakteristik peserta didik dan kondisi sekolah? (Ya), apakah memanfaatkan lingkungan alam dan/atau sosial? (Tidak), apakah menggunakan buku teks pelajaran dari pemerintah (buku pegangan guru dan siswa)? (Ya), apakah merujuk materi-materi yang diperoleh melalui perpustakaan? (Tidak), apakahmerumuskan kegiatan pembelajaran yang mencakup kegiatan pendahuluan, inti, dan penutup? (Ya), apakah merancang pengelolaan pembelajaran yang sistematis dan sistemik, memuat aktivitas-aktivi4as yang mefcungkap kegiatan mengamati, menanxa, mungumpulkan informasi, meog`soséasi, mengkomunikasikan, dan bika memU gkinkan sampai dengan(mEncipta? (Ya), apaoah m\}rancang aktivitas pembelajaran\$yang menfasilitasi tergapai ya`smmua $\mathrm{k} \square$ mpetensi (melgembangkan sik`p,(pengetahuan, dan keterampilan)? (Ya), apakah merumqskan a+tivitas pembelajaran $\$$ sesuai dengal karakteristik peserta didik, alokasi waktu, sarana, dan media pembelakaran? (Ya(, apakah mEncantumkan teknkk, bentuk, dan instrõmen penilaian padaoranah sikaq spiritual, sikap sosial, pengetahuqn, ean keterampilal? (Ia)

Apakah mencantumkan teknik, bentuk,!dan instrumen penilAian ya.g Sesuai dengan indikator? (Ya), apakah mengembangkan pedoman peoskoran (termasuk rubrik) sesuai dengan instrumen? (Ya), apakah merumuskan kegiatan pembelajaran remddial yang!sesuaI den'an karakterirtik xesertc dhdik, aloKasi wajtu, sarana, dan mgdi! pembelajaran? (Ya), apekah menuliskan ak4ivitas kegiatan pembelajaran \$remelial yang dapat berupa: (1) pembelajaran ulang; (2) bimbingan perorangan; dan (3) belajar kelompok atau tutor teman sebaya? (Tidak), apakah merumuskan kegiatan pembelajaran pengayaan yang memuat perluasan/pendalaman materi pembelajaran dan/atau mempertinggi kompetensi? (Tidak), apakah menuliskan aktivitas kegiatan pembelajaran pengayaan yang bisa berupa: (1) proyek, yang meliputi perencanaan, pembuatan produk, pelaporan dan mengerjakan soal-soal yang menuntutkemampuan berpikir lebih tinggi? (Tidak)

\section{Pengamatan Pelaksanaan Pembelajaran}

Kegiatan yang dilakukan dalam tahap ini adalah guru melaksanakan rencana pembelajaran yang telah disiapkan sebelumnya, yakni berupa kegiatan belajar mengajar. Kemudian peneliti melakukan pengamatan terhadap guru dan siswa selama proses pembelajaran berlansung, untuk itu peneliti terlebih dahulu mempersiapkan pedoman pengamatan kegiatan pembelajaran yang telah disusun dalam bentuk pernyaan, yaitu sebagai berikut :

Apakah guru menyiapkan peserta didik untuk mengikuti proses pembelajaran? (Ya), apakah guru mengondisikan suasana belajar yang menyenangkan? (Tidak), apakah guru menyampaikan kompetensi yang akan dicapai dan manfaatnya dalam kehidupan sehari-hari? (Ya), apakah guru mengajukan pertanyaan-pertanyaan yang mengaitkan pengetahuan sebelumnya dengan materi yang akan dipelajari? (Tidak), apakah guru mengantarkan peserta didik kepada suatu permasalahan yang akan dilakukan? (Ya), apakah guru menjelaskan tujuan pembelajaran atau kompetensi dasar yang akan dicapai? (Tidak), apakah guru menyampaikan cakupan materi yang akan dibahas? (Ya), apakah guru menjelaskan uraian kegiatan yang akan dilaksanakan sesuai silabus? (Tidak), apakah guru menyampaikan lingkup dan teknik penilaian yang akan digunakan? (Tidak), apakah guru telah menguasai dan mengembangkan materi pembelajaran? (Ya), apakah guru telah mengelola pembelajaran yang mengembangkan kreativitas? (Ya), apakah pelaksanaan pembelajaran sesuai dengan tujuan yang akan dicapai? (Ya), apakah guru memfasilitasi peserta didik untuk melakukan pengamatan? (Tidak), apakah guru memfasilitasi peserta didik untuk bertanya sesuai dengan konteks materi yang dipelajari? (Ya), apakah guru memfasilitasi peserta didik untuk mengumpulkan informasi? (Ya), apakah guru memfasilitasi peserta didik untuk mengasosiasi atau mengolah informasi? (Tidak), apakah guru memfasilitasi peserta didik untuk mengkomunikasikan hasil? (Tidak), apakah dalam proses pembelajaran guru menggunakan sumber belajar berbasis aneka sumber belajar? (Tidak), apakah dalam proses pembelajaran guru memberikan penguatan menggunakan pendekatan ilmiah? (Tidak), apakah dalam proses pembelajaran guru mengembangkan keterampilan aplikatif? (Ya), apakah ada peningkatan dan keseimbangan antara keterampilan fisikal (hardskills) dan keterampilan mental (softskills) peserta didik? (Ya), apakah pembelajaran mengutamakan pembudayaan dan pemberdayaan peserta didik sebagai pembelajar sepanjang hayat? (Ya), apakah guru menerapkan nilai-nilai dengan memberi keteladanan, membangun kemauan, dan mengembangkan kreativitas peserta didik dalam proses pembelajaran? (Ya), apakah guru menerapkan prinsip bahwa siapa saja adalah guru, siapa saja adalah siswa, dan di mana saja adalah kelas? (Tidak), apakah guru memanfaatkan teknologi informasi dan komunikasi untuk meningkatkan efisiensi dan efektivitas pembelajaran? (Tidak), apakah guru menguasai karakter peserta didik? (Ya), apakah guru menguasai teori belajar dan prinsip pembelajaran berbasis metode ilmiah? (Ya), apakah guru membuat rangkuman/simpulan pelajaran? (Tidak), apakah guru melakukan refleksi terhadap kegiatan yang sudah dilaksanakan? (Tidak), apakah guru memberikan umpan balik terhadap proses dan hasil Pembelajaran? (Ya), apakah guru melakukan penilaian yang meliputi pengetahuan, sikap, dan keterampilan? (Ya), pakah guru merencanakan kegiatan tindak lanjut dalam bentuk pembelajaran remedi, program pengayaan, layanan konseling? (Tidak), apakah guru memberikan kegiatan tindak lanjut dalam bentuk pemberian tugas, baik tugas individual maupun kelompok? (Ya), apakah guru menyampaikan rencana pembelajaran pada pertemuan berikutnya? (Tidak)

3. Hasil Belajar

Adapun hasil belajarberdasarkan dokumen yang diberikan oleh Bapak/Ibu Guru PPKn yang 
bersangkutan dengan pedoman wawancara yang telah diuraikan dalam bentuk pertanyaan, yaitu sebagai berikut:

Apakah hasil belajar peserta didik pada ranah pengetahuan memenuhi standar KKM yang ditetapkan oleh satuan pendidikan tertentu? (Ya), apakah hasil belajar peserta didik pada ranah sikap spiritual mencerminkan aspek pengetahuan dan keterampilan sebagai dampak pengiringnya? (Ya), apakah hasil belajar peserta didik pada ranah sikap sosial mencerminkan aspek pengetahuan dan keterampilan sebagai dampak pengiringnya? (Tidak), apakah hasil belajar peserta didik pada ranah keterampilan sesuai dengan pengetahuan yang dipelajarinya? (Ya)

Perencanaan pembelajaran pada dasarnya merupakan persiapan guru dalam menyampaikan dan menerima pelajaran di kelas, perencanaan dilakukan agar meminimalkan kegagalan dalam menyampaikan pelajaran yang akan dilakukan. Guru akan menyampaikan semua hal yang berkaitan dengan materi yang akan disampaikan pada waktu tertentu dengan metode dan media yang akan dapat menunjang proses pengajaran serta pembelajaran. Bentuk rencana pelaksanaan pembelajaran (RPP) dikembangkan dari silabus dan silabus memiliki kompetensi inti (KI), Kompetensi dasar (KD) dan Indikator pembelajaran. Guru kemudian akan menyusun RPP sesuai dengan kurikulum yang digunakan.

Pada Kurikulum 2013 (K13) Rencana pelaksanaan pembelajaran (RPP) merupakan rencana pembelajaran yang dikembangkan secara rinci mengacu pada silabus, buku teks pelajaran, dan buku panduan guru. RPP mencakup: (1) identitas sekolah/madrasah, mata pelajaran, dan kelas/semester; (2) alokasi waktu; (3) KI, $\mathrm{KD}$, indikator pencapaian kompetensi; (4) materi pembelajaran; (5) kegiatan pembelajaran; (6) penilaian; dan (7) media/alat, bahan, dan sumber belajar.

Setiap guru wajib menyusun RPP untuk mata pelajaran yang diampunya. Pengembangan RPP dilakukan sebelum semester atau tahun pelajaran dimulai, namun perlu diperbaharui sebelum pembelajaran dilaksanakan. Pengembangan RPP dapat dilakukan oleh guru secara mandiri dan/atau berkelompok di sekolah/madrasah dikoordinasi, difasilitasi, dan disupervisi oleh kepala sekolah/madrasah.

Pengembangan RPP dapat juga dilakukan oleh guru secara berkelompok antarsekolah atau antarwilayah dikoordinasi, difasilitasi, dan disupervisi oleh dinas pendidikan atau kantor Kementerian Agama setempat.

Adapun pengamatan pelaksanaan pembelajaran dilaksanakan pada tanggal 3 sampai 30 maret yang dilaksanakan di MTS Labuan Bajo Kab. Manggarai Barat. Pada kegiatan pendahuluan guru menyiapkan peserta didik untuk mengikuti proses pembelajaran dan menyampaikan kompetensi yang akan dicapai serta manfaatnya dalam kehidupan sehari-hari kemudian mengantarkan peserta didik pada suatu permasalahan yang akan dilakukan, tetapi belum sepenuhnya mengondisikan suasana belajar dengan baik dan tidak mengajukan pertanyaan-pertanyaan yang mengaitkan pengetahuan sebelumnya dengan materi yang akan di pelajari, guru langsung menyampaikan cakupan materi yang akan dibahas dan tidak menyampaikan lingkup dan teknik penilaian yang akan digunakan.
Pada kegiatan inti guru telah meguasai dan mengembangkan materi pembelajaran sesuai dengan tujuan yang akan dicapai serta memfasilitasi peserta didik untuk bertanya sesuai dengan konteks materi yang dipelajari, tetapi dalam prosese pembelajaran guru seringkali tidak memberikan penguatan menggunakan pendekatan ilmiah dan langsung memberikan apresiasi kepada peserta didik yang dapat menjawab pertanyaan dari temannya kemudian langsung memberikan kesempatan bertantanya kepada peserta didik yang lainnya. Dalam proses pembelajaran guru mengembangkan ketrampilan aplikatif peserta didik seperti keterampilan fisikal (hardskills) dan keterampilan mental (softskills), tetapi guru belum menerapkan prinsip bahwa siapa saja adalah guru, siapa saja adalah siswa dan dimana saja adalah kelas serta belum memanfaatkan media teknologi informasi dan komunikasi karena masih kurangnya sarana dan prasarana yang ada disekolah sehingga guru tidak bisa menampilkan contoh permasalahan yang sedang dipelajari.

Pada kegiatan penutup guru memberikan umpan balik terhadap proses dan hasil pembelajaran, melakukan penilaian yang meliputi pengetahuan dan keterampilan, memberikan kegiatan tindak lanjut dalam bentuk tugah kelompok berupa, tetapi guru tidak merencanakan kegiatan tindak lanjut dalam bentuk pembelajaran remidi dan program pengayaan dan tidak menyampaikan rencana pembelajaran pada pertemuan berikutnya.

Adapun hasil belajar peserta didik pada ranah pengetahuan telah memenuhi standar KKM yang telah ditentukan oleh satuan pendidikan tertentu yaitu dengan nilai rata-rata 7,5-90 dan pada ranah sikap spiritual serta keterampilan telah sesuai dengan pengetahuan yang dipelajarinya seperti ikut melaksanakan ibadah solat jum'at yang diselenggarakan dimesjid sekolah, mengajak teman sebaya untuk mengikuti kegiatan imtaq dan mengingatkan temannya untuk sholat zhuhur disekolahnya, tetapi pada ranah sikap social belum mencermikan seperti pada aspek pengetahuan yang dipelajarinya.

Berdasarkan hasil dokumentasi dan wawancara terhadap perencanaan pembelajaran yang telah disusun oleh guru dalam bentuk rencana pelaksanaan pembelajaran (RPP), maka dapat dikatakan bahwa rencana pelaksanaan pembelajaran (RPP) yang disusun oleh guru telah sesuai dengan peraturan menteri pendidikan dan kebudayaan No.22 tahun 2016 mengenai standar proses pendidikan dasar dan menengah walaupun ada beberapa hal masih kurang seperti belum merumuskan tujuan pembelajaran sesuai dengan kompleksitas KD, sarana dan prasarana yang tersedia serta tidak memanfaatkan variasi media pembelajaran dan tidak merujuk pada materi-materi yang ada diperpustakaan.

Berdasarkan hasil observasi penelitian terhadap pelaksanaan pembelajaran dari awal hingga akhir proses pembelajaran, maka dapat dikatakan secara keseluruhan pelaksanaan pembelajaran belum sepenuhnyadilaksanakan dengan baik sesuai dengan tahap dan proses yang direncanakan dalam rencana pelaksanaan pembelajaran (RPP), masih adanya hal-hal yang belum diterapkan oleh guru seperti tidak menyampaikan lingkup dan teknik penialain yang akan digunakan, tidak menggunakan sumber belajar berbasis 
aneka sumber belajar, guru tidak tida memberikan penguatan menggunakan pendekatan ilmiah dan tidak menerapkan prinsip bahwa siapa saja adalah guru, siapa saja adalah siswa dan dimana saja adalah kelas, danrespon peserta didik selama proses pembelajaran yang dilakukan oleh guru, sebagian besar peserta didik kurang menyukai jalannya proses belajar mengajar, hal ini disebabkan karena guru terlalu focus pada materi sehingga peserta didik ada yang mengantuk dan bosan.

\section{SIMPULAN DAN SARAN}

Berdasarkan uraian di atas, maka disimpulkan beberapa hasil penelitian menunjukkan bahwa:

Program pembelajaran PPKn di MTs Labuan Bajo Kab. Manggarai Barat pada bagian perencanaan pembelajaran yang disusun dalam bentuk rencana pelaksanaan pembelajaran (RPP) yang meliputi: Identitas sekolah, mata pelajaran atau tema/subtema, kelas/semester, materi pokok, dan alokasi waktu, Kompetensi Inti (KI), Kompetensi Dasar (KD), Indikator Pencapaian Kompetensi, Tujuan Pembelajaran, Materi Pembelajaran, Metode Pembelajaran, Media Pembelajaran, Sumber Belajar, Kegiatan Pembelajaran, Penilaian,Pembelajaran, dan Pengayaan, telah disusun oleh guru dengan baik sesuai dengan peraturan mentri pendidikan dan kebudayaan No. 22 tahun 2016 mengenai standar proses pendidikan dasar dan menengah.

Pada tahap pelaksanaan pembelajaran PPKn yang dilaksanakan oleh guru yang meliputi : kegitan pendahuluan, kegiatan inti dan kegiatan penutup belum sepenuhnya dilaksanakan sesuiadengan rencana pelaksanaan pembelajaran (RPP) yang telah disusun dan belum sesuai dengan peraturan mentri pendidikan dan kebudayaan No. 22 tahun 2016 mengenai standar proses pendidikan dasar dan menengah.

Pada hasil penilaian berdasarkan dokumen yang diberikan oleh Bapak/Ibu Guru PPKn yang bersangkutan yang meliputi : hasil belajar peserta didik pada ranah pengetahuan, hasil belajar peserta didik pada ranah keterampilan, hasil belajar peserta didik pada ranah sikap, telah sesuai dengan peraturan mentri pendidikan dan kebudayaan No. 22 tahun 2016 mengenai standar proses pendidikan dasar dan menengah

Untuk itu, kepada para guru dan pemerintah dapat disarankan terutama bagi sekolah MTs Labuan Bajo Kab. Manggarai Barat diharapkan dapat memfasilitasi seluruh keperluan siswa dan guru yang akan menunjang prestasi siswa dalam hal belajar mengajar, dan Guru, diharapkan dapat mempertahankan cara mengajar seperti yang telah dilakukan atau lebih ditingkatkan lagi dengan menggunakan berbagai media yang menarik agar kemampuan siswa semakin bisa diasah sesuai dengan keunggulan masing-masing. Memfasilitasi majalah dinding atau website agar siswa semakin tertarik dan lebih aktif, dan mereka akan merasa bahwa mata pelajaran PPKn adalah mata pelajaran yang menyenangkan.

\section{UCAPAN TERIMA KASIH}

Penulis mengucapkan terima kasih kepada editor yang senantiasa memberikan saran dan masukan kepada penulis sehingga artikel ilimiah ini selesai dengan baik.

\section{DAFTAR RUJUKAN}

[1] N. S. Sukmadinata, "Metode penelitian kualitatif," Bandung. ID PT. Remaja Rosdakarya, 2011.

[2] M. Djamal, "Paradigma Penelitian Kualitatif," Yogyakarta: Pustaka Pelajar, 2015.

[3] A. Suharsimi, "Prosedur penelitian suatu pendekatan praktik,” Jakarta: Rineka Cipta, 2006.

[4] P. Sugiyono, Metode Penelitian Kuantitatif, Kualitatif, dan $R \& D .2013$.

[5] I. Djumhur and M. Surya, "Bimbingan dan penyuluhan di sekolah," Bandung CV Ilmu, 1975. 